\title{
Penerapan Pembelajaran Tematik Dalam Penanaman Moral Anak Usia Dini
}

\author{
Nur Asiyah ${ }^{1}$ \\ ${ }^{1}$ Raudlatul Athfal Nurul Islam, Jambi, Indonesia
}

\begin{tabular}{l} 
Article Info \\
\hline Article history: \\
Received Mei 8, 2020 \\
Revised Mei 16, 2020 \\
Accepted Mei 28, 2020 \\
\hline
\end{tabular}

\section{Keywords:}

Anak Usia Dini

Pembelajaran Moral

Tematik

\begin{abstract}
ABSTRAK
Tujuan Penelitian: Bagaimanakah penerapan pembelajaran tematik untuk penanaman moral anak usia dini di Raudlatul Athfal Nurul Islam Bandar Jaya, Tanjung Jabung Timur.
\end{abstract}

Metodologi: Penelitian ini merupakan penelitian deskriptif kualitatif yang bertujuan untuk menggambarkan secara objektif keadaan ditempat penelitian dengan menggunakan rangkaian kata-kata atau kalimat, dengan subjek penelitian adalah anak kelas B1 yang berjumlah 23 anak. Alat pengumpulan data yang penulis gunakan adalah observasi, wawancara dan dokumentasi.

Temuan Utama: Hasil penelitian menunjukkan bahwa perkembangan pelaksanaan pembelajaran Tematik sudah cukup baik. Manfaat pembelajaran tematik dapat dilihat dari perubahan perkembangan moral anak. Perkembangan moral berkembangan dari sebelumnya karena moral anak semakin bertambah. Pelaksanaaan pembelajaran tematik dapat mengembangkan penanaman moral anak usia dini di Raudlatul Athfal Nurul Islam Bandar Jaya, Tanjung Jabung Timur cukup baik dalam mengembangkan penanaman moral anak melalui pembelajaran tematik sebagai model pembelajaran, dengan diperlukan langkah-langkah sebagai berikut: penyusunan perencanan pembelajaran, pelaksanaan pembelajaran, evaluasi pembelajaran

Aplikasi dalam Penelitian: Penanam karakter sangat diperlukan menyambut kurikulum yang diajukan oleh pemerintah sekarang, maka dari itu diperlukan pembelajaran yang bisa diintegrasikan salah satunya pembelajaran tematik.

Keterbarauan: Pembelajaran tematik dapat diintegrasikan untuk menunmbuhkan moral anak usia dini.

Copyright (C) 2020 Cahaya Ilmu Cendekia Publisher. All rights reserved.

\section{Corresponding Author:}

Nur Asiyah

Raudlatul Athfal Nurul Islam, Jambi, Indonesia

Email: RahayuributHB@gmail.co.id

\section{PENDAHULUAN}

Pendidikan adalah usaha sadar dan terencana untuk mewujudkan suasana belajar dan proses pembel ajaran agar peserta didik secara aktif mengembangkan potensi dirinya untuk memiliki kekuatan spiritual keag amaan, pengendalian diri, kepribadian, kecerdasan, akhlakul mulia, serta keterampilan yang diperlukan dirinya, masyarakat, bangsa, dan Negara [1]. Pendidikan merupakan bagian penting dari kehidupan sekaligus membedakan manusia dengan makhluk lainnya. Hewan juga "belajar" tetapi lebih ditentukan oleh instingnya. Sedangkan manusia belajar merupakan rangkain kegiatan menuju pendewasaan guna menuju kehidupan yang lebih berarti [2]. Menurut Undang-Undang Sisdiknas No. 20 tahun 2003 yang menyatakan bahwa "pendidikan adalah usaha sadar dan terencana untuk mewujudkan suasana belajar dan proses pembelajaran agar peserta didik aktif mengembangkan potensi dirinya untuk memiliki kekuatan spiritual 
keagamaan, pengendalian, kepribadian, kecerdasan, akhlak mulia, serta keterampilan yang dimiliki dirinya, masyarakat, bangsa dan Negara [3].

Pendidikan Anak Usia Dini (PAUD) adalah individu yang sedang mengalami proses pertumbuhan dan perkembangan yang sangat pesat, bahkan dikatakan sebagai lompatan perkembangan. Sejumlah ahli berpendapat bahwa ketika bayi dilahirkan, dia seperti tabula rasa atau kertas kosong. Pikiran seorang anak merupakan hasil dari pengalaman dan proses belajar. Pengalaman dan proses belajar yang diperoleh melalui indera membentuk manusia menjadi individu yang unik [4]. Mansur mengemukakan bahwa Pendidikan Anak Usia Dini (PAUD) adalah pemberian upaya untuk menstimulasi, membimbing, mengasuh, dan pemberian kegiatan pembelajaran yang akan menghasilkan kemampuan dan keterampilan anak. Pendidikan anak usia dini merupakan salah satu bentuk penyelenggaraan yang menitikberatkan pada peletakkan dasar kearah pertumbuhan dan perkembangan fisik (koordinasi motorik halus dan motorik kasar), kecerdasan (daya pikir, daya cipta, kecerdasan emosi dan kecerdasan spiritual, sosial emosional (sikap perilaku serta agama), bahasa dan komunikasi [5]. Pendidikan anak usia dini atau yang sering disingkat dengan PAUD sedang menjadi fokus perhatian masyarakat. Masyarakat mulai tertarik untuk memperbincangkan Pendidikan Anak Usia Dini setelah mengetahui berbagai manfaat yang diperoleh jika anak-anak mereka diberi stimulasi positif sejak dini. Ketertarikan tersebutlah yang kemudian menjadikan lembaga-lembaga Pendidikan Anak Usia Dini tumbuh dan berkembang begitu pesatnya laksana jamur yang tumbuh di musim penghujan dan semakin banyaknya orang tua yang menyekolahkan anak-anaknya di lembaga tersebut [6].

Dari beberapa aspek perkembangan diatas penulis tertarik untuk melakukan sebuah penelitian yang berkaitan dengan penanaman moral anak. Karena Pentingnya pendidikan moral dalam kehidupan manusia telah di perbincangkan dalam berbagai sudut pandang pendidikan akhlak dalam islam dapat dipahami dalam al-quran dan hadis [7]. Ibnu sina juga mengatakan bahwa kehidupan itu adalah akhlak, tiada kehidupan tanpa akhlak (prilaku individu). Penekanan akhlak ini juga sudah ada sejak jaman Yunani demi member kebaikan kepada pembentukan sesuatu bangsa [8]. Dan pendidikan moral pada dasarnya saat ini merupakan topik yang sangat penting diperbincangkan dikalangan pendidikan, pendidikan moral di yakini sebagai aspek penting dalam peningkatan sumber daya manusia (SDM), karena turut menentukan kemajuan suatu bangsa. Dan dalam ensiklopedi pendidikan, moral dikatakan sebagai nilai dasar dalam masyarakat untuk menentukan baik buruknya suatu tindakan yang pada akhirnya menjadi adat istiadat kelompok masyarakat [9].

Para akhli psikologi anak telah membuktikan bahwa usia dibawah lima tahun merupakan masa peletak dasar dari pertumbuhan dan perkembangan dimasa-masa selanjutnya [10]. Anak usia dini pada hakikatnya adalah manusia yang memerlukan bimbingan dalam memahami nilai-nilai moral yang ada di masyarakat baik di rumah maupun di sekolah. Sebagaimana yang diungkapkan oleh Piaget, Perkembangan moral anak usia 2-6 tahun berada dalam tahapan moralitas melalui paksaan, bahwa anak dalam tahapan secara otomatis mengakui peraturan-peraturan tanpa berpikir atau menilai dan menganggap orang dewasa yang berkuasa [11]. Hal tersebut memiliki makna bahwa seorang anak pada saat awal kehidupannya belum memiliki pendirian yang kuat dalam menentukan sikap dan perilakunya, karena anak-anak masih cenderung labil, mudah terbawa arus dan mudah terpengaruh.

Selanjutnya Menurut Kholbreg perkembangan moral anak usia prasekolah (PAUD) berada pada tingkatan yang paling mendasar yang dinamakan dengan penalaran moral [12]. Pada tingkat ini anak belum menunjukan internalisasi moral (secara kokoh). Pendidikan karakter merupakan suatu sistem penanaman moral kepada peserta didik yang meliputi komponen: kesadaran, pemahaman, dan komitmen yang tinggi untuk melaksanakan nilai-niali tersebut, baik terhadap Allah Tuhan yang Maha Esa, diri sendiri, sesama, lingkungan, maupun masyarakat dan bangsa keseluruhan sehingga menjadi manusia sempurna sesuai dengan kodratnya [13]. Pendidikan karakter harus dilakukan secara kholistik dari semua lingkungan pendidikan yaitu keluarga sekolah dan masyarakat [14]. Apa bila terjadi kesalahan dalam memberikan pendidikan pada anak usia dini atau usia awal akan berdampak negatif pada kehidupan anak selanjutnya. Seorang anak akan memperoleh pengalaman yang pertama dalam lingkungan keluarga dan hal tersebut akan menjadi pengalaman yang berharga bagi anak. Orang tua sebagai bagian terdekat dengan anak memiliki kewajiban untuk mendidik dan membimbing moral anak. Sehingga anak dapat berperilaku sesuai dengan ajaran agama yang dianut maupun tuntunan sosial yang ada di masyarakat, karena pada dasarnya anak-anak dilahirkan seperti kertas putih. Maka Orang tua sangat berperan untuk menjadikan anak-anaknya sebagai bentuk bagian dari keluarga untuk berprilaku yang baik.

Sebagaimana Firman Allah SWT yang telah ditegaskan dalam Q.S Al-kahfi: 46 yang Artinya :Harta dan anak-anak adalah perhiasan kehidupan dunia tetapi amalan-amalan yang kekal lagi saleh adalah lebih baik pahalanya disisi tuhannya serta lebih baik unuk menjadi harapan (Al-Kahfi:46) [15]. Berdasarkan keterangan firman Allah SWT Diatas, maka dapat disimpulkan bahwa anak adalah satu-satunya perhiasan dunia, maka kedua orang tuanya yang membentuk kepribadian anak dan bergantung kepada para pendidik. Sehingga lebih baik dalam perkembangan fitrah anak dilakukan pada saat usia dini. Pada umumnya sebagian

JBER. Vol. 1, No. 2, Mei 2020: 45 - 53 
orang yakin bahwa guru memiliki andil yang sangat besar terhadap keberhasilan pembelajaran kepribadian anak dan bergantung kepada para pendidik [16].

Menurut pendapat para pakar dapat penulis simpulkan bahwa perkembangan moral anak usia 5-6 tahun adalah suatu kemampuan untuk berinteraksi dengan tingkah laku yag baik sesuai dengan norma-norma, sehingga menimbulkan perilaku yang baik dan buruk. Moral juga merupakan bagian dari identitas seseorang, jika ia menunjukkan perilaku yang baik, orang akan memberikan penilaian yang positif tentang dirinya, begitu pula sebaliknya. Moral juga akan menuntun seseorang dalam kehidupannya di masyarakat, dengan moral perilaku yang baik seseorang akan memperoleh citra positif sehingga memiliki tempat yang baik didalam kehidupan bermasyarakat, namun jika ia berperilaku buruk, maka citranya menjadi buruk dan sangat sukar diterima oleh masyarakat. Moral yang biasa dikaitkan dengan perilaku memiliki pengaruh yang besar dalam kehidupan seseorang. Jika sejak dini seseorang tidak memiliki bekal pengetahuan yang baik mengenai moral dan bagaimana cara berperilaku yang baik terhadap dirinya maupun orang disekitarnya, maka hal itu dapat menimbulkan penyimpangan perilaku di kemudian hari. Minimnya pengetahuan moral yang mereka miliki, serta kurangnya perhatian orang tua terhadap anak karena orang tua sibuk memenuhi segala kebutuhan hidup (tuntutan ekonomi), menjadi salah satu faktor mengapa saat ini banyak terjadi penyimpangan perilaku sosial dan jelas sekali terlihat betapa buruknya moral dalam bertingkah laku mereka dalam bermasyarakat. Menanamkan moral pada anak, dapat dilakukan ketika mereka memasuki usia sekolah. Karena disekolah anak akan menemukan berbagai pengalaman baru, seperti teman dan lingkungan yang baru (asing) bagi mereka, dimana anak mulai beradaptasi dengan lingkungan sekitar mereka [17].

Berdasarkan pengamatan prasurvey yang dilakukan peneliti di Raudlatul Athfal As-Salam Jati Agung Lampung Selatan diperoleh suatu gambaran bahwa peserta didik yang ada pada perkembangan moral anak belum berkembang dengan baik. Hal ini dipengaruhi oleh beberapa faktor, seperti kurangnya metode serta media yang tepat dalam mengembangkan moral anak, sehingga anak sering kali merasa bosan, jenuh dan mengakibatkan perkembangan moral pun kurang. Permasalahan yang muncul adalah keterlambatan atau lemahnya aspek moral anak. Terkait tentang indikator perkembangan moral anak usia dini, Di dalam buku Nilawati Tadjuddin kohlberg mendefinisikan indikator moral dapat di kembangkan pada anak usia dini diantaranya sebagai berikut: Indikator Perkembangan Moral Anak Usia Dini Usia 5-6 Tahun Yaitu:

1. Kerjasama

2. Bergiliran

3. Disiplin diri

4. Kejujuran

5. Tanggung Jawab

6. Bersikap sopan dan berbahasa yang santun[18]

Dari hasil pengamatan awal dapat dipahami bahwa penanaman moral agama anak di Raudlatul Athfal Nurul Islam Bandar Jaya, Tanjung Jabung Timur belum berkembang sesuai harapan. Selama penulis melakukan pengamatan, penulis melihat anak yang belum berkembang (BB) ada 10 anak dengan presentase $44,44 \%$, dan yang tergolong mulai berkembang (MB) ada 10 anak dengan pre sentase 44,44\%, sedangkan hanya 3 orang anak saja yang sudah tergolong berkembang sesuai harapan (BSH) dengan peresentase $0,1 \%$. Sedangkan anak yang berkembang sesuai harapan (BSB) $0 \%$. Hal tersebut menunjukan perlunya adanya peran komunikasi verbal dan non verbal dalam penanaman moral agama Raudlatul Athfal As-Salam Jati Agung Lampung Selatan. Jadi dapat disimpulkan bahwa penanaman moral agama anak di Raudlatul Athfal Nurul Islam Bandar Jaya, Tanjung Jabung Timur belum berkembang secara optimal. Oleh sebab itu pembelajaran yang di lakukan oleh guru dalam memberikan pendidikan kepada anak harus mencangkup enam aspek perkembangan pada anak. Dalam memberikan bimbingan kepada anak sebagai seorang guru harus memiliki kopetensi sebagai guru profesional yang sesuai dengan UUD Guru dan Dosen No 14 tahun 2005 ialah guru wajib memiliki loyaliti dan akreditasi, kualifikasi akademik, kopetensi sijil pendidikan, tanggung jawab[19]. Beberapa potensi tersebut membantu guru dalam mencapai tujuan pembelajaran yang diinginkan [20]. Tugas guru tidak hanya melahirkan pelajaran yang cemerlang dalam akademik tetapi juga bertanggung jawab membentuk akhlak dan sahsiah pelajaran kearah yang lebih baik [21]

Mengingat pentingnya pendidikan anak usia dini perlu adanya pendekatan yang tepat dan efektif dalam proses pembelajarannya. Peran guru dalam pembelajaran harus memperhatikan aspek-aspek dalam menunjang kualitas pengajaran di kelas, guru yang kompeten akan dapat menyajikan pembelajaran sesuai dengan kebutuhan sehingga proses pembelajaran menjadi menyenangkan bagi anak. Peran guru harus didasari atas komitmen mendidik dengan tujuan mulia yaitu melahirkan generasi-generasi masa depan yang unggul dan cerah. Memiliki guru yang profesional merupakan kunci keberhasilan bagi kegiatan belajar mengajar disekolah, Suyanto, melakukan penelitian yang hasilnya menunjukan bahwa peran guru amat signifikan bagi setiap keberhasilan proses pembelajaran karena ketika guru telah memasuki ruang kelas dan menutup pintu kelas maka kualitas pembelajaran akan lebih banyak ditentukan oleh guru. Sebagaimana yang 
tercantum dalam PP RI No. 19 tahun 2005 tentang kualifikasi kompetensi yang harus dimiliki oleh guru meliputi kompetensi pedagogik, kompetensi professional, kompetensi kepribadian dan kompetensi

Pembelajaran tematik sangat tepat diterapkan dalam pembelajaran untuk anak usia dini karena dengan pemilihan tema-tema tersebut dapat membangun dan mengembangkan seluruh aspek perkembangan anak. Karena dengan pembelajaran yang sebenarnya anak berprilaku baik. Oleh sebab itu pihak gurulah yang harus berperan aktif dalam pembelajaran untuk anak. Sebagaimana yang di ungkapkan menurut Aisyah pembelajaran tematik adalah pendekatan yang digunakan dalam kegiatan belajar mengajar dengan mengintegrasikan kegiatan yang mewakili semua bidang kurikulum atau bidang-bidang pengembangan yang meliputi aspek kognitif, bahasa, fisik/motorik, seni, sosial emosional, moral. Semua bidang pengembangan yang ada dijabarkan ke dalam kegiatan-kegiatan belajar yang berpusat pada satu tema, oleh karena itu pembelajaran terpadu di Taman Kanak-kanak disebut juga pembelajaran tema [22].

Berdasarkan temuan permasalahan-permasalahan tersebut dan mengingat betapa pentingnya Penanaman Moral anak usia dini, maka penulis termotivasi untuk melakukan penelitian yang berjudul: "Penerapan Pembelajaran Tematik Dalam Penanaman Moral Agama Anak Di Raudlatul Athfal Nurul Islam Bandar Jaya, Tanjung Jabung Timur."

\section{METODE PENELITIAN}

Penelitian ini menggunakan metode kualitatif deskriftif. Penelitian Tersebut dikatakan deskriftif karena apa yang dilakukan dan dikatakan oleh pelaku, Proses yang sedang berlangsung dan berbagai aktifitas lain dalam konteks ilmiah, maka penelitian mesti mendeskripsikan atau menggambarkan segala sesuatu yang diraihnya secara lengkap rinci, dan mendalam [23]. Dengan demikian dapat disimpulkan bahwa penelitian deskriptif adalah suatu penelitian dimana peneliti berusaha memotret pristiwa dan kejadian yang menjadi pusat perhatian untuk kemudian digambarkan atau dilukiskan apa adanya. Adapu penelitian ini menggambarkan kondisi dilapangan tentang penerapan pembelajaran tematik dalam penanaman moral anak di Raudlatul Athfal Nurul Islam Bandar Jaya, Tanjung Jabung Timur.

Penelitian ini dilaksanakan di Raudlatul Athfal Nurul Islam Bandar Jaya, Tanjung Jabung Timur. Penelitian ini akan dilaksanakan pada awal tahun ajaran baru 2018/2019. Penentuan waktu penelitian mengacu pada kalender akademik sekolah, karena dalam penelitian kualitatif memerlukan beberapa penelitian yang membutuhkan proses belajar mengajar yang efektif dikelas. Subjek penelitian adalah subjek yang dituju untuk diteliti oleh peneliti. Dalam penelitian kualitatif ini yang menjadi subjek penelitian adalah Kelompok B1 Raudlatul Athfal Nurul Islam Bandar Jaya, Tanjung Jabung Timur.dengan jumlah siswa yang terdiri dari 23 siswa dengan komposisi perempuan 12 siswa dan laki-laki 11siswa.

Penelitian ini menggunakan wawancara bebas terpimpin wawancara akan dilakukan untuk mewawancarai, guru, untuk memperoleh data tentang "Penerapan Pembelajaran Tematik dalam Penanaman Moral Anak Usia Dini di Raudlatul Athfal Nurul Islam Bandar Jaya, Tanjung Jabung Timur”. Selain itu peneliti menggunakan metode obersvasi. Observasi disini dilakukan dengan observasi partisipan dan observasi non partisipan.

Teknik analisis data yang dilakukan antara lain memfokuskan pada hal-hal yang penting untuk dicari tema dan polanya (data reduction), kemudian data disajikan dalam sebuah pola yang sesuai dengan kajian (data display), dan setelah itu ditarik sebuah kesimpulan yang menghasilkan sebuah hipotesis dan deskripsi atau gambaran suatu objek yang sebelumnya masih remang-remang atau gelap menjadi jelas (conclusion drawing) atau (verification) [24].

\section{HASIL DAN PEMBAHASAN}

Pada bagian ini akan membahas tentang pengolahan dan analisis data yang telah diperoleh melalui penelitian yang dilakukan, dengan menggunakan metode dan instrument yang penulis tentukan pada bab sebelumnya. Adapun data tersebut penulis dapatkan melalui observasi dan wawancara sebagai metode pokok dalam pengumpulan data.

Penulis menggunakan dokumentasi sebagai metode yang mendukung untuk melengkapi data yang tidak penulis dapatkan melalui observasi dan wawancara. Penelitian ini merupakan penelitian deskriptif dan kualitatif, yang mana hasil dari observasi, wawancara dan dokumentasi yang telah penulis lakukan. Penelitian ini dilakukan oleh penulis di Raudhatul Athfal Assalam Jati Agung Lampung Selatan pada tanggal 23 Juli 23 Agustus 2018 dapat diketahui bahwa jumlah peserta didik kelompok B1 berjumlah 23 anak terdiri 11 orang anak laki-laki, 12 orang anak perempuan dan 2 tenaga pendidik. Kegiatan pembelajaran tematik untuk mengembangkan moral anak di Raudhatul Athfal Assalam Jati Agung Lampung Selatan, ternyata menghasilkan moral anak yang cukup baik. Berikut penulis sajikan pembahasan dan analisis data sebagai langkah selanjutnya dalam penarikan kesimpulan, sebagai berikut:

JBER. Vol. 1, No. 2, Mei 2020: 45 - 53 
Pengolahan analisa data yang diperoleh melalui penelitian yang dilakukan., dimana data tersebut penulis dapatkan dari hasil wawancara dan observasi sebagai metode pokok dalam pengumpulan data, untuk mengambil suatu keputusan yang obyektif dan dapat berfungsi sebagai fakta yang ada di lapangan. Penelitian ini berawal dari observasi yang penulis lakukan di Raudhatul Athfal Assalam Jati Agung Lampung Selatan untuk mengamati bagaimana penerapan pembelajaran tematik dalam penerapan moral anak di Raudhatul Athfal Assalam Jati Agung Lampung Selatan.

Menganalisis data, penulis menggunakan metode deskriptif, yang berarti metode ini mengambil kesimpulan hasil observasi kegiatan belajar mengajar dan interview pada guru Raudhatul Athfal Assalam Jati Agung Lampung Selatan. Setelah data terkumpul, maka dilanjutkan dengan induktif, yaitu menganalisis data yang bertitik tolak dari fakta-fakta yang bersifat khusus kemudian disimpulkan secara umum. Adapun hal yang penulis analisis adalah penerapan pembelajaran tematik dalam penanaman moral anak usia dini. Mengetahui pelaksanaan kegiatan penerapan pembelajaran tematik dalam mengmbangkan moral anak di Raudlatul Athfal Nurul Islam Bandar Jaya, Tanjung Jabung Timur tahun pelajaran 2018/2019 peneliti mengdakan observasi dan wawancara di kelompok B1. Adapun hasil observasi dan wawancara yang peneliti lakukan yaitu ada beberapa langkah kegiatan penerapan pembelajaran tematik yang dilakukan guru.

Berdasarkan hasil penelitian anak di Raudhatul Athfal Assalam Jati Agung Lampung Selatan dapat diuraikan bahwa penerapan pembelajaran tematik dalam penanaman moral anak usia dini sebagai berikut:

\section{Kerjasama}

Kerjasama adalah orang yang membantu orang lain atau lingkungan sekitar, sikap kerjasama dapat membuat kita menjalin hubungan yang baik kepada sesama manusia di dalam islam setiap muslim saling kerjasama sebagai mana di jelaskan dalam (Q.S al-Maidah Ayat 2)

Artinya: Dan tolong-menolonglah kamu dalam (mengerjakan) kebajikan dan takwa, dan jangan tolong-menolong dalam berbuat dosa dan pelanggaran. dan bertakwalah kamu kepada Allah, Sesungguhnya Allah Amat berat siksa-Nya.

Kerjasama dapat kita ajarkan kepada anak usia dini melalui ligkungan kita atau contoh kita sendiri. Berdasarkan hasil observasi yang penulis lakukan mengenai penanaman moral melalui pembelajaran tematik dengan langkah guru melakukan perencanaan pembelajaran tematik, pelaksananaan pembelajaran tematik dan mengevalusi pembelajaran tematik Dengan indikator anak dapat kerjasama, terdapat 9 anak yang perkembangan moralnya sudah berkembang sangat baik, terlihat dari anak saat memerankan sebagai seorang guru dan anak-anak lainnya dapat kerjasama yaitu saling membantu temannya, dan anak dapat menyelesaikan tugas secara berkelompok, 11 anak berkembang sesuai harapan, dan 3 anak mulai berkembang.

\section{Bergiliran}

Berdasarkan hasil observasi yang penulis lakukan mengenai penanaman moral melalui pembelajaran tematik dengan langkah guru melakukan perencanaan pembelajaran tematik, pelaksanaan pembelajaran dan evaluasi Dengan indicato $r$ anak bisa bergiliran yaitu sabar menunggu giliran saat mencuci tangan.

Perkembangan moral dari indikator tersebut didapatkan data ada 8 anak sudah menunjukkan berkembang sangat baik, dapat dilihat dari anak dapat bersabar saat menunggu giliran saat mencuci tangan ada 4 anak berkembang sesuai harapan, dan 11 anak mulai berkembang.

\section{Disiplin diri}

Berdasarkan hasil observasi yang penulis lakukan mengenai penanaman moral melalui pembelajaran tematik dengan langkah perencanaan pembelajaran tematik, pelaksanaan pembelajaran tematik, evaluasi pembelajaran tematik Dengan indicator disiplin diri yaitu datang kesekolah tepat waktu, dan anak dapat merapihkan Perkembangan moral dari indikator tersebut didapatkan data 5 anak berkembang sangat baik, 12 anak berkembang sesuai harapan, dan 6 anak mulai berkembang.

\section{Jujur}

Jujur adalah sikap seseorang ketika berhadapan dengan sesuatu atau fenomena dan menceritakannya informasi tanpa ada perubahan atau sesuai dengan realitas sikap jujur dapat kita ajarkan atau tanamkan kepada anak sejak usia dini. islam sikap jujur juga dijarakan di dalam islam dimana dalam $\mathrm{Al}$ - Quran surat $\mathrm{Al}-\mathrm{Ahzab}$ ayat $70-71$

Artinya: Hai orang-orang yang beriman, bertakwalah kamu kepada Allah dan Katakanlah Perkataan yang benar, niscaya Allah memperbaiki bagimu amalan-amalanmu dan mengampuni bagimu dosa-dosamu. dan Barangsiapa mentaati Allah dan Rasul-Nya, Maka Sesungguhnya ia telah mendapat kemenangan yang besar. [Al-Ahzab : 70 - 71] 
Dari ayat diatas bahwa orang beriman itu haruslah berkata benar atau jujur, sikap jujur ini dapat kita ajarkan kepada anak dari usia dini sehingga saat anak dewasa anak telah terbiasa dalam berprilaku jujur

Berdasarkan hasil observasi yang penulis lakukan mengenai penanaman moral melalui pembelajaran tematik dengan langkah guru melakukan perencanaan pembelajaran tematik, pelaksanaan pembelajaran dan evaluasi Dengan indicator anak bisa beryaitu sabar menunggu giliran saat mencuci tangan. Perkembangan moral dari indikator tersebut didapatkan data ada 8 anak sudah menunjukkan berkembang sangat baik, dapat dilihat dari anak dapat bersabar saat menunggu giliran saat mencuci tangan ada 4 anak berkembang sesuai harapan, dan 11 anak mula berkembang.

\section{Tanggung Jawab}

Berdasarkan hasil observasi yang penulis lakukan mengenai penanaman moral melalui pembelajaran tematik dengan langkah guru melakukan perencanaan pembelajaran tematik, pelaksanaan pembelajaran dan evaluasii Dengan indicator anak bisa bertanggung jawab yaitu Anak dapat merapihkan kembali pakaian setelah BAB dan BAK, Anak dapat mentaati peraturaan saat cuci tangan, mau meminta maaf dan memberi maaf.. Perkembangan moral dari indikator tersebut didapatkan data ada 7 anak sudah menunjukkan berkembang sangat baik, dapat dilihat dari anak dapat bersabar saat menunggu giliran saat mencuci tangan ada 8 anak berkembang sesuai harapan, dan 8 anak mulai berkembang

\section{Bersikap sopan dan berbahasa yang santun}

Berdasarkan hasil observasi yang penulis lakukan mengenai penanaman moral melalui pembelajaran tematik dengan langkah guru melakukan perencanaan pembelajaran tematik, pelaksanaan pembelajaran dan evaluasi dengan indikator anak bisa bersikap sopan dan berbahasa yang santun yaitu anak berbicara yang baik dengan sesama teman, anak dapat menghormati teman guru dan orang yang lebih tua. Perkembangan moral indkator tersebut didapatkan data ada 9 anak sudah menunjukan berkembang sangat baik, dapat dilihat dari anak dapat bersabar saat menunggu giliran saat mencuci tangan ada 9 anak berkembang sesuai harapan, dan 5 anak mulai berkembang

Berdasarkan hasil observasi dan wawancara mengenai penanaman moral melalui pembelajaran temtik pada anak usia di Raudlatul Athfal Nurul Islam Bandar Jaya, Tanjung Jabung Timur, dapat penulis uraikan langkah-langkah pelaksanaan pembelajaran temtik, yaitu:

\section{Perencanaan pembelajaran tematik}

Hasil observasi yang dilakukan di RA As-salam Kecamatan Jati Agung Lampung Selatan pada langkah ini, merupakan kegiatan awal dalam kegiatan Pembelajaran tematik yaitu diawali dengan pemilihan tema terlebih dahulu, dalam membuat perencanaan menetapkan tujuan dan tema. Guru memilih tema untuk kegiatan yang ingin dicapai. Yakni guru menganalisis kurikulum Taman Kanak-kanak (kurikulum 2013) melalui program semester, yang kemudian dibuat Rencana Kegiatan Mingguan (RKM), dan dibuat Rencana Pelaksanaan Pembelajaran Harian (RPPH). Setiap RPPH memuat kegiatan dari setiap tema yang akan diturunkan menjadi subtema dan kemudian disesuaikan dengan penerapan pembelajaran tematik dalam penanaman moral dan sebagai penilaian progres perkembangan anak. ${ }^{6}$

\section{Pelaksanaan pembelajaran tematik}

Berdasarkan hasil observasi di Raudlatul Athfal Nurul Islam Bandar Jaya, Tanjung Jabung Timur, guru sudah mengintegrasikan nilai moral ke dalam setiap kegiatan pembelajaran tematik, dari awal hingga akhir pembelajaran. Guru menciptakan pembelajaran yang dialogis dan interaktif dengan menerapkan berbagai metode pembelajaran. Guru juga menciptakan suasana belajar yang memungkinkan anak untuk berkompetisi secara sehat melalui berbagai penugasan dan metode pembelajaran lainnya. Implementasi penanaman moral yang dilakukan guru dapat dilihat mulai dari kegiatan pendahuluan, kegiatan inti, dan kegiatan penutup.

Pada kegiatan inti, guru mengimplementasikan beberapa kegiatan. Guru selalu memulai kegiatan pembelajaran dengan mengajak siswa berdoa bersama. Pada kegiatan inti, guru menerapkan berbagai metode pembelajaran seperti metode bernyanyi, pembiasaan, tanya jawab dan pemberian tugas. Selanjutnya peneliti dapat menyimpulkan, bahwa pengintegrasian nilai-nilai moral dalam proses pembelajaran dapat berjalan efektif dengan menggunakan metode pembelajaran.

Berdasarkan hasil penelitian, dalam pembelajaran tematik guru menggunakan materi pelajaran menjadi bahan atau media untuk mengembangkan nilai-nilai penanaman moral . Berdasarkan hasil observasi, tema yang sedang dipelajari adalah "Lingkunganku." Secara garis besar, pokok-pokok yang dipelajari meliputi lingkunnganku dengan sub tema (rumahku, sekolahanku, keluargaku), berbagai macam lingkunganku, berbagai macam profesi, usaha yang dilakukan oleh seseorang untuk meraih cita-cita tertentu, dan nilai-nilai karakter yang dapat diteladani dari cita-cita atau profesi tertentu. Materi yang dipelajari ada

JBER. Vol. 1, No. 2, Mei 2020: 45 - 53 
yang berupa teks bacaan tentang cita-cita tertentu dan gambar profesi tertentu. Guru menggali pesan moral yang dapat diteladani oleh siswa yang terdapat dalam materi tersebut.

\section{Evaluasi Pembelajaran Tematik}

Berdasarkan hasil observasi di Raudlatul Athfal Nurul Islam Bandar Jaya, Tanjung Jabung Timur, Pembelajaran di kelas diawali dengan merancang kegiatan pembelajaran. Salah satu aspek yang harus ada dalam perencanaan adalah tujuan pembelajaran serta cara mencapai tujuan. Untuk mengetahui ketercapaian tujuan pembelajaran perlu dilakukan penilaian. Dalam penilaian atau evaluasi pembelajaran tematik yang dilakukan guru tidak hanya dinilai dalam hasil belajar saja namun dalam proses pembelajaran guru harus menilai kegiatan peserta didik.

Kegiatan penerapan pembelajaran tematik Raudlatul Athfal Nurul Islam Bandar Jaya, Tanjung Jabung Timur diawali dengan perencanaan pembelajaran yang dilakukan oleh guru, hal ini bertujuan agar proses kegiatan yang akan dilakukan akan berjalan lebih berstuktur. Kemudian dilanjutkan dengan pelaksanaan pembelajaran yang akan diterapkan kepada anak sehingga lebih maksimal ketika proses pembelajaran berlangsung. Disini penulis melihat pelaksanaan pembelajaran tematik melalui proses Perencanan pembelajaran tematik, pelaksanaan, evaluasi. perkembangan anak usia dini, di era yang sekarang ini seharusnya guru lebih kreatif dengan pembelajaran tentang pembelajaran tematik sehingga pembelajaran tematik terus berkembang dan dapat menngembangkan perkembangan anak terkhusus perkembangan moral anak.Setelah melihat upaya yang dilakukan oleh ke dua guru pada kelompok B1 Raudlatul Athfal Nurul Islam Bandar Jaya, Tanjung Jabung Timur dengan berdasarkan langkah-langkah yang diterapkan serta indikator pencapaian yang sesuai dengan perkembangan anak usia dini, maka penulis mendapat hasil data observasi perkembangan moral anak usai dini dengan menggunakan pembelajaran temati.

Tabel 2. Hasil Akhir Penanaman Moral Anak Raudlatul Athfal As-Salam Jati Agung Lampung Selatan

\begin{tabular}{|c|c|c|c|c|c|c|c|}
\hline \multirow{2}{*}{ Nama } & \multicolumn{6}{|c|}{ Indikator Moral } & \multirow[t]{2}{*}{ Ket } \\
\hline & 1 & 2 & 3 & 4 & 5 & 6 & \\
\hline A1 & $\mathrm{MB}$ & $\mathrm{BSH}$ & $\mathrm{BSH}$ & $\mathrm{BSH}$ & MB & $\mathrm{BSH}$ & $\mathrm{BSH}$ \\
\hline $\mathrm{A} 2$ & $\mathrm{BB}$ & $\mathrm{BB}$ & $\mathrm{BB}$ & $\mathrm{BB}$ & $\mathrm{BB}$ & $\mathrm{BB}$ & $\mathrm{BSH}$ \\
\hline A3 & MB & $\mathrm{BB}$ & MB & MB & MB & MB & $\mathrm{BSH}$ \\
\hline A4 & MB & $\mathrm{BB}$ & $\mathrm{MB}$ & $\mathrm{BB}$ & MB & MB & $\mathrm{BSH}$ \\
\hline A5 & $\mathrm{BSH}$ & BB & $\mathrm{MB}$ & $\mathrm{BSH}$ & BSH & BSH & BSH \\
\hline A6 & $\mathrm{BB}$ & $\mathrm{BB}$ & $\mathrm{BSH}$ & $\mathrm{BB}$ & MB & MB & MB \\
\hline A7 & MB & $\mathrm{BB}$ & $\mathrm{MB}$ & $\mathrm{BSH}$ & MB & MB & $\mathrm{BSH}$ \\
\hline A8 & $\mathrm{BSH}$ & $\mathrm{MB}$ & $\mathrm{MB}$ & $\mathrm{BB}$ & MB & $\mathrm{BSH}$ & MB \\
\hline A9 & MB & $\mathrm{MB}$ & $\mathrm{BB}$ & MB & BB & MB & BSH \\
\hline A10 & $\mathrm{BB}$ & $\mathrm{BSH}$ & $\mathrm{MB}$ & $\mathrm{BB}$ & BB & $\mathrm{BB}$ & $\mathrm{BSH}$ \\
\hline A11 & $\mathrm{BSH}$ & BB & $\mathrm{MB}$ & $\mathrm{BSH}$ & BSH & $\mathrm{BSH}$ & BSH \\
\hline A12 & $\mathrm{MB}$ & $\mathrm{MB}$ & $\mathrm{MB}$ & BB & MB & $\mathrm{MB}$ & MB \\
\hline A13 & MB & $\mathrm{MB}$ & $\mathrm{MB}$ & MB & MB & MB & $\mathrm{MB}$ \\
\hline A14 & BB & MB & $\mathrm{BB}$ & $\mathrm{MB}$ & BB & $\mathrm{BB}$ & MB \\
\hline A15 & $\mathrm{MB}$ & $\mathrm{MB}$ & $\mathrm{MB}$ & MB & BB & $\mathrm{MB}$ & MB \\
\hline A16 & BB & BB & $\mathrm{BB}$ & MB & BB & $\mathrm{BB}$ & MB \\
\hline A17 & BSH & BSH & BSH & BSH & BSH & BSH & BSH \\
\hline A18 & BB & $\mathrm{MB}$ & BB & BB & BB & $\mathrm{BB}$ & MB \\
\hline A19 & BB & $\mathrm{MB}$ & $\mathrm{MB}$ & MB & $\mathrm{BSH}$ & MB & $\mathrm{MB}$ \\
\hline A20 & BB & MB & $\mathrm{MB}$ & $\mathrm{MB}$ & MB & MB & MB \\
\hline A 21 & BB & MB & $\mathrm{MB}$ & $\mathrm{MB}$ & MB & MB & MB \\
\hline A 22 & MB & MB & $\mathrm{MB}$ & MB & BB & MB & $\mathrm{MB}$ \\
\hline A 23 & $\mathrm{MB}$ & $\mathrm{MB}$ & $\mathrm{MB}$ & $\mathrm{MB}$ & MB & MB & MB \\
\hline
\end{tabular}

Ket:

BB : BelumBerkembang

MB : Mulai Berkembang

BSH : Berkembang Sesuai Harapan

BSB : Berkembang Sangat Baik

1. Kerjasama

2. Bergiliran

Penerapan Pembelajaran Tematik Dalam Penanaman Moral Anak Usia Dini (Nur Asiyah) 

3. Disiplin diri
4. Jujuran
5. Tanggung jawab
6. Bersikap sopan dan berbahasa yang santun.

Berdasarkan data hasil observasi akhir dari tabel di atas dapat disimpulkan bahwasannya guru telah berusaha semaksimal mungkin dengan selalu melakukan penggunaan pembelajaran tematik dalam penananaman moral anak usia dini. Langkah-langkah yang diterapkan pembelajaran tematik dalam penanaman moral anak usia dini di Raudhatul Athfal As-Salam Jati Agung Lampung Selatan, telah menunjukkan hasil yang optimal.

Berkaitan analisis data yang bersifat deskriftif maka bagian ini akan peneliti uraikan hasil observasi dan wawancara dari penerapan pembelajaran tematik dalam penanaman moral anak di Raudlatul Athfal AsSalamJati Agung Lampung Selatan. bahwa pertama guru dan anak bersama-sama membahas tentang tema. Tema dan sub tema dipilih dan di sesuaikan dengan pembelajaran yang akan di lakukan. Kedua, guru memberikan motivasi melalui cerita dan menunjukan gambar-gambar yang sesuai dengan tema. Gambargambar yang diberikan guru berupa gambar yang bisa membuat anak merasa tertarik mengikuti permainan. Melalui gambar tersebut anak akan menjadi tertantang dan juga semangat karna bisa membuat suatu karya dalam bentuk nyata. Ketiga, guru mengenalkan bahan- bahan dan alat penunjang atau permainan lain yang akan digunakan. Sebelum bermain anak guru perlu mengenalkan alat-alat permainan yang akan dipakai. Guru harus memberitahu setiap nama-nama dari bahan- bahan yang akan dipakai, setelah itu guru mulai memberi contoh cara pembelajarannya agar menjadi suatu bentuk yang diinginkan.

Selanjutnya, guru juga harus memberitahu tata tertib pembelajarannya Hal tersebut perlu dilakukan karna mengingat anak dalam pemproses pembelajran ada yang sering tidak hati-hati, ada yang berebutan dengan temannya dan tidak menyelesaikan apa yang guru perintahkan jadi guru harus mengawasi anak-anak ketika bermain agar mereka tidak saling berebut dan melempar bahan -bahan pada temannya yang lain. Kemudian anak mulai melakukan perintah guru, dan tugas guru mengawasi anak-anak yang sedang bekerja atau ikut bermain dan smbil belajar dan tidak lupa pula saling memberi motivasi jika diperlukan. Hal tersebut senada dengan tahapan pembelajaran tematik yang diungkapkan oleh Aisyah adalah pendekatan yang digunakan dalam kegiatan belajar mengajar dengan mengintegrasikan kegiatan yang mewakili semua bidang kurikulum atau bidang-bidang pengembangan yang meliputi aspek kognitif, bahasa, fisik/motorik, seni, sosial emosional, moral. Semua bidang pengembangan yang ada dijabarkan ke dalam kegiatan-kegiatan belajar yang berpusat pada satu tema, oleh karena itu pembelajaran terpadu di Taman Kanak-kanak disebut juga pembelajaran tema [25].

Menurut Sujiono menyatakan pembelajaran tematik merupakan "Pembelajaran yang melibatkan berbagai bidang pengembangan untuk memberikan pengalaman yang bermakna kepada anak."pembelajaran tematik melibatkan pengembangan fisik, bahasa, kognitif, perkembangan moral, sosial, dan emosional anak secara menyeluruh [26]. Menurut Ujang Sukandi, mengartikan pembelajaran tematik atau terpadu sebagai kegiatan mengajar dengan memadukan materi dari beberapa mata pelajaran dalam satu tema [27]. Menurit Trianto Menjelaskan bahwa Pembelajaran tematik pada dasarnya adalah model pembelajaran terpadu yang menggunakan tema untuk mengaitkan beberapa mata pelajaran sehingga dapat memeberikan pengalaman bermakana kepada siswa [28]. Dari kegiatan yang telah dilakukan oleh anak khususnya dalam mengembangkan moral dengan konstruksi menggunakan pembelajaran tematik banyak sekali yang didapatkan oleh anak bukan hanya perkembangan moral tetapi juga perkembangan sosial emosional, kognitif, bahasa fisik motorik.

Dari hasil observasi dan wawancara yang sudah peneliti lakukan dapat diambil kesimpulan bahwa penerapan pembelajaran tematik dalam penanaman moral anak usia dini menunjukkan perubahan yang signifikan seperti anak menonjol dalam disiplin yaitu datang kesekolah tepat waktu, kerjasama yaitu saling membantu sesama teman, begiliran yaitu anak sabar menunggu giliran, tanggung jawab yaitu anak dapat bertanggung jawab dengan tugasnya.

\section{KESIMPULAN}

Berdasarkan hasil analisis dan data yang telah diuraikan penulis menyimpulkan bahwa Penerapan pembelajaran tematik dalam dalam penanaman moral di Raudhatul Athfal Assalam Jati Agung Lampung Selatan sudah baik. Hal ini menunjukkan bahwa penerapan pembelajaran tematik dapat mengambangkan moral anak. Perkembangan moral anak akan berkembang lebih optimal jika pembelajaran yang digunakan mendukung terhadap bahan ajar yang akan disampaikan, dengan Penerapan pembelajaran tematik maka akan dapat meningkatkan perkembangan moral anak.

JBER. Vol. 1, No. 2, Mei 2020: 45 - 53 


\section{UCAPAN TERIMA KASIH}

Terimakaish kepada seluruh responden yang telah bersedia, sehingga penelitian ini dapat saya selesaikan. Serta semua elemen yang telah ikut berpartisipasi, saya ucapkan terimakasih

\section{REFERENSI}

[1] Sani, I. K. "Implementasi Kurikulum 2013 Konsep dan Penerapan". Kata Pena, Surabaya. 2014

[2] Djamarah. "Prestasi Belajar dan Kompetensi Guru". Usaha Nasional. Surabaya, 1994

[3] R. Putri Bintari,. I. N. Sudiana. "Pembelajaran Bahasa Indonesia Berdasarkan Pendekatan Saintifik (Problem Based Learning) Sesuai Kurikulum 2013 Di Kelas Vii Smp Negeri 2 Amlapura". E- Journal Program Pascasarjana Universitas Pendidikan Ganesha, 3(1), 1-10, 2014

[4] A. D. Daryanto. "Pengembangan Perangkat Pembelajaran (Silabus, RPP, PHB, Bahan Ajar)". Gava Media. Yogyakarta, 2014

[5] A. Asrial., S. Syahrial., M. Maison., D. A. Kurniawan., \& S. O. Piyana. Ethnoconstructivism E-Module to Improve Perception, Interest, And Motivation of Students in Class V Elementary School. JPI (Jurnal Pendidikan Indonesia), vol. 9 , no, 1, 2020.

[6] Asrial., Syahrial., D. A. Kurniawan, \& Suci Okta Piyana. "E-Modul Etnokontruktivisme: Implementasi pada Kelas V Sekolah Dasar Ditinjau Dari Persepsi, Minat dan Motivasi." JTP-Jurnal Teknologi Pendidikan, vol. 21, no. .2 pp. 165-177, 2019

[7] M. H. Azis. "Kurikulum Tingkat Satuan Pendidikan (KTSP) Sekolah Menengah Atas (SMA)". ALLEMANIA, vol. 2, no. 2, 2013

[8] A. Azhar, \& R. A. A. Rahim. "Aplikasi Elemen Pemikiran Saintifik Dalam Pengajian Syariah". Jurnal Fiqh, vol. 7, no. 7, pp. 1-28, 2020 Retrieved from http://myais.fsktm.um.edu.my/12437/

[9] K. Kuswanto. "Where is The Direction Of Physics Education?." Jurnal Pijar Mipa vol. 15, no. 1, pp. 59-64, 2020

[10] A. Machin. "Implementasi pendekatan saintifik, penanaman karakter dan konservasi pada pembelajaran materi pertumbuhan". Jurnal Pendidikan IPA Indonesia, 3(1), 28-35, 2014 https://doi.org/10.15294/jpii.v3i1.2898

[11] R. Asyhar. "Kreatif Mengembangkan Media Pembelajaran". Gaung, Jakarta, 2010

[12] P. Andi. "Panduan Kreatif Membuat Bahan Ajar Inovatif". Diva Press, Jogjakarta, 2013

[13] Darmaji, Darmaji, \& D. A. Kurniawan. "Persepsi Mahasiswa Pendidikan Biologi dan Pendidikan Kimia terhadap Penggunaan Buku Panduan Praktikum Fisika Dasar Berbasis Mobile learning." EDUSAINS 11.2 (2019).

[14] R. M. Branch. "Ustructional Design: The ADDIE Aprroach". Springer Science. London, 2009

[15] S. Arikunto. "Dasar-Dasar Evaluasi Pendidikan". Bumi Aksara, Jakarta, 2013

[16] H. Nurul. "Pengertian dan Langkah-Langkah Saintifik". Gava Media Persada., Yogyakarta, 2013

[17] S. A. G. Azhary., I. G. P. Suryadarma., P. L. Devitasari., \& K. Kuswanto. "Development of Science E-Flipbook Integrated Illegal Sand Mining on River Basin to Improve Environmental Care Attitude". IJECA (International Journal of Education and Curriculum Application), vol. 3, no. 1, pp. 26-30, 2020.

[18] J. Marjan, I. B. P. Arnyana. "Pengaruh Pembelajaran Pendekatan Saintifik Terhadap Hasil Belajar Biologi Dan Keterampilan Proses Sains Siswa MA. Mu allimat NW Pancor Selong Kabupaten Lombok Timur Nusa Tenggara Barat”. Jurnal Pendidikan IPA, vol. 4, no. 1, 2014. https://doi.org/10.1089/omi.2012.0013

[19] Kurniawan, Wawan, et al. "Multimedia Physics Practicum Reflective Material Based on Problem Solving for Science Process Skills." International Journal of Evaluation and Research in Education, vol. 8, no. 4, pp. 590-595 2019

[20] Astalini, Darmaji. "Motivation and Attitude of Students on Physics Subject in the Middle School in Indonesia." International Education Studies, vol. 12, no. 9, 2019

[21] Hariyadi, Bambang, \& D. A. Kurniawan. "Deceiving the Queen: Integrating Jambinese Traditional Honey Gathering into Science Learning." BIODIK, vol. 4, no. 2, pp. 60-76, 2018 